\title{
Social behaviour in the non-breeding season in Great Tits Parus major and Willow Tits Poecile montanus: differences in juvenile birds' route to territorial ownership, and pair-bond stability and mate protection in adults
}

\author{
Olav Hogstad
}

Norwegian University of Science and Technology, NTNU University Museum, NO-7491 Trondheim, Norway; e-mail: Olav.Hogstad@ntnu.no

\begin{abstract}
Great Tits Parus major and Willow Tits Poecile montanus are small passerine monogamous species that live in dominance-structured flocks outside the breeding season. Within such flocks, males dominate females, and within sex, adults generally dominate juveniles (first-year birds). However, whereas Willow Tits maintain a yearlong defence of large territories and their flocks have a constant membership, the Great Tits maintain looser organizations of their flocks that vary in size, and the birds move around irrespective of territorial ranges. I compared the aggressive behaviour between juvenile conspecifics of Great and Willow Tits from July through April during 2004-2014, and the intra-pair behaviour of adults during November-February in 2011-2014 in a subalpine forest in Budal, central Norway. Two maxima of aggressive interactions were found among juveniles of both species: one in AugustSeptember and one in March-April. For Great Tits the autumn-interactions were probably due to competition for food, whereas the spring-interactions reflected competition for territorial space. For Willow Tits, the interactions in August - September were caused by competition for flock membership and ownership for a territory in March-April. Because flock membership in general is the only possible way to territory ownership, also the aggressive behaviour among juvenile Willow Tits in autumn is most likely linked to territorial behaviour. I found three circumstances of immediate benefits of the pair bond for adult Willow Tits that are consistent with the hypothesis of mate protection and that differed from that of Great Tit pairs: Willow Tits had a shorter intra-pair distance, females received less aggression, and they had a higher foraging rate when accompanied by their mate than did females of Great Tit pairs. One out of the five Great Tit pairs studied became divorced, whereas the bonds of three Willow Tit pairs were stable over at least three to four years.
\end{abstract}

Key words: Aggressive interaction; pair-bond stability; mate protection; social behaviour

\section{INTRODUCTION}

Great Tits Parus major and Willow Tits Poecile montanus encounter the same environmental conditions during the winter time, viz. long nights, low ambient temperatures, snow-covered trees, and the possibility of periods of food shortages. Both species are monogamous and live in dominance-structured flocks outside the breeding season. However, whereas Willow Tits live in habitats largely saturated with territory owners and maintain a yearlong defence of large territories (20-25 ha) and their "winter flocks" generally have a constant membership (e.g. Hogstad 1999), Great Tits live in looser organizations of winter flocks and many adults leave their relatively small territories (about 2-3 ha) in the autumn and form flocks with conspecifics from other territories (e.g. Saitou 1978). These birds move around irrespective of their dominance position or to territories or flock ranges, and the flock size is therefore not constant, but is assumed to be dependent on the distribution and abundance of food (Gosler 1993).

The winter flocks of Willow Tits consist most often of an adult mated pair, referred to as the alpha pair, and one or two pairs of unrelated first-year Willow Tits that have settled after a post-natal dispersal. Pair formation of juveniles may occur as early as 1-2 weeks after dispersal and before establishment in territories of adult, or during the process of the winter flock formation in August-September (Hogstad 2014). As the number of juveniles produced in an area is larger than the number established in winter flocks in autumn, many juveniles fail to become flock members and are forced to be nonresidents with few chances of surviving the following winter. Since flock membership may be the only chance for juveniles to breed in the area the following spring 
(Hogstad 2003), fighting for membership may be intense during the flock establishment period. Great Tit flocks, often consisting of an alpha pair and one to four juveniles, move around and make temporary assemblages of all or some members from neighbouring flocks. Such aggregations of conspecifics are frequently found where food is concentrated (Gosler 1993). The level of aggression is high, particularly when visiting juveniles enter the area.

Interactions, most frequently among first-year tits, are intense during autumn and late winter for both species, and often involve chasing of one bird by another (e.g. DeLaet 1984, Hogstad 2003). Although such seasonally aggressive behaviour has been described earlier, quantifying of chasings over the course of the winter is scanty. In this study I quantify the interactions among conspecific tits during the non-breeding season.

Based upon previous reports, it is assumed that the aggressive behaviour of juvenile Great Tits in autumn is related to food, and that such observations in late winter are a result of territorial contests (e.g. DeLaet 1984, Gosler 1993), whereas the aggressive behaviour of juvenile Willow Tits is linked to ownership of a prospective territory both in autumn and winter (e.g. Hogstad 2003). If so, the route to territorial ownership differs between the two species. It may therefore be suggested that (1) juvenile Great Tits should react to play-back songs of conspecifics only in late winter, i.e. during territory establishment, whereas juvenile Willow Tits should react to song play-back both in autumn and late winter.

Because alpha pairs of Willow Tits stay within their territory year-round and remain mated across years (Hogstad unpublished data), and alphas of Great Tits frequently leave their territory outside breeding season and live in loose aggregations, it may be suggested that mate attentiveness is higher in Willow Tits than in Great Tits. I therefore expected that Willow Tit alpha pairs should keep closer together and spend more time in association with each other outside the breeding season than Great Tit pairs, and that mate fidelity and mate protection are highest in Willow Tits.

If so, the following predictions can be formulated: (2) The mean intra-pair distance of Willow Tits in winter flocks should be less than that of Great Tits. (3) When being close together at a food resource, the dominant alpha Willow Tit male should attack his mate less compared to that of the dominant alpha Great Tit, and (4) when accompanied by her mate, the alpha Willow Tit female should spend less time being vigilant and more time foraging than the alpha Great Tit female.

\section{MATERIAL AND METHODS}

The field work was done from July through April during 2004-2014 in a subalpine mixed forest composed of
Scots Pine Pinus sylvestris and Downy Birch Betula odorata in Budal, in central Norway (ca. $\left.63^{\circ} \mathrm{N}\right)$. The winter weather most often sets in about mid-October. Potential predators of the tits in the area are small mustelids (stoat Mustela erminea and weasel $M$. nivalis), small owls such as Tengmalm's Owl Aegolius funereus and Hawk Owl Surnia ulula in twilight or at night, and Sparrowhawk Accipiter nisus, Siberian Jay Perisoreus infaustus and Great Grey Shrike Lanius excubitor during the day.

Most of the tits were colour-ringed. They were caught in feeder traps during July-November (mainly September-October), individually ringed and aged as juveniles or adults and sexed on the basis of plumage (Willow Tits: Laaksonen \& Lehikoinen 1976, Hogstad 1987; Great Tits: Svensson 1992). The size and composition of the flocks were determined on the basis of the degree of coherence observed among the birds (Ekman 1979) during the period August-November. The hierarchical order of the individuals within each flock was determined by observing the outcome (winners and losers) of agonistic encounters at feeders (Hogstad 1987). The results confirm previous reports that in both the Willow Tit (Hogstad 1987) and the Great Tit (Saitou 1978), males dominate females, and within sex, adults generally dominate juveniles (adult male $>$ juvenile male $>$ adult female $>$ juvenile female).

To quantify the aggression between juveniles of the two species, I counted the number of aggressive interactions (most frequently one bird chasing another) observed along a track of ca. $1 \mathrm{~km}$ for Great Tits and another track of ca. $5 \mathrm{~km}$ for Willow Tits, during August-April in 2004-2014. In total 81 surveys (monthly totally 5-18) of Great Tits and 232 surveys (monthly totally 15-37) of Willow Tits were made. Ambient temperature was registered at the start of each trip. To determine whether the aggression was caused by territorial behaviour, I played back song of Great and Willow Tits, respectively, when encountering a flock and observed the reaction of the juvenile birds. A reaction was noted as positive when a bird stopped foraging and approached the recorder. In total, 14 playbacks were done, each about one minute, six over several days in August-September and eight in MarchApril.

To assess the mate attentiveness, the locations of adult mated pairs (ringed birds that have bred together) were recorded where first observed, and the distance (in metres) between the mates was noted. When staying in the same tree, the value 1 was used. To reduce statistical dependence between the observations, only one record was made per individual pair per day. In total, 39 records of five different Great Tit pairs and 71 records of three Willow Tit pairs were made during November-February in 2011-2014.

Possible intra-pair conflicts were studied when an alpha female was staying at a feeder and her mate 
Table 1. Monthly number of surveys and aggressive chasings of Great Tits and Willow Tits observed along a fixed track during the non-breeding seasons of 2004-2014 in a subalpine forest in central Norway. The length of the track was about $1 \mathrm{~km}$ for Great Tits and about $5 \mathrm{~km}$ for Willow Tits.

\begin{tabular}{|c|c|c|c|c|c|c|}
\hline \multirow[t]{2}{*}{ Month } & \multicolumn{3}{|c|}{ Great Tit } & \multicolumn{3}{|c|}{ Willow Tit } \\
\hline & surveys & chasings & $\begin{array}{c}\text { Mean } \\
\text { chas./survey }\end{array}$ & surveys & chasings & $\begin{array}{c}\text { Mean } \\
\text { chas./survey }\end{array}$ \\
\hline August & 6 & 6 & 1.0 & 31 & 42 & 1.4 \\
\hline September & 5 & 6 & 1.2 & 20 & 35 & 1.8 \\
\hline October & 5 & 4 & 0.8 & 26 & 11 & 0.4 \\
\hline November & 18 & 2 & 0.1 & 16 & 0 & 0 \\
\hline December & 8 & 0 & 0 & 15 & 0 & 0 \\
\hline January & 11 & 0 & 0 & 30 & 0 & 0 \\
\hline February & 11 & 0 & 0 & 34 & 2 & 0.1 \\
\hline March & 11 & 8 & 0.7 & 37 & 39 & 1.1 \\
\hline April & 6 & 10 & 1.7 & 23 & 43 & 1.9 \\
\hline
\end{tabular}

approached. The feeders were provided with sunflower seeds during the observational hours only. Totally, 16 and 25 records were made of Willow and Great Tits, respectively, in 2011-14. I also studied the effect of a conspecific male that approached an adult female (within $2 \mathrm{~m}$ or less) staying at a feeder. The different activities recorded were foraging and vigilance. When foraging, the bird held the tip of its bill below eye level; when vigilant, the tip of its bill was raised to eye level or higher (see Lendrem 1983, Hogstad 1992). Three contexts were considered: (1) when she foraged solitarily, (2) with her mate, and (3) with a conspecific juvenile. Totally, 39 and 29 records were made of Willow Tits and Great Tits, respectively, in 2011-14.

\section{RESULTS \\ Juvenile birds \\ Flocking and aggressive encounters}

In the nearest weeks after the breeding season, adult Great Tits stayed on or near their territory without territorial activity. Most of the juveniles apparently had left the area. During the autumn and early winter, small flocks, each composed of an adult pair and one to three juveniles, travelled around and formed larger flocks or aggregations at feeder points. The adult Willow Tit pairs stayed within their territories together with one or two pairs of unrelated first-year tits. The competition for a flock membership could be intense among the juvenile Willow Tits. After flock establishment, however, conflicts among flock members were rare.

Two maxima of aggressive interactions were observed in the two species: one in August-September and one in March-April (Table 1 and Figure 1). Because these interactions (most frequently one bird that chased another) rarely involved colour-ringed adult birds, but were among ringed young or unmarked birds, I considered that the majority of the interactions observed were among juveniles.

The mean number of chasings per trip among Great Tits during August-September was 1.0 \pm 0.54 SD (n $=11)$ and during March-April $1.1 \pm 0.75(\mathrm{n}=17)$, among Willow Tits $1.5 \pm 0.86(\mathrm{n}=51)$ and $1.4 \pm 1.04$ $(\mathrm{n}=60)$ during August-September and March-April, respectively. Within species, no difference was found between the means of these autumn and spring maxima

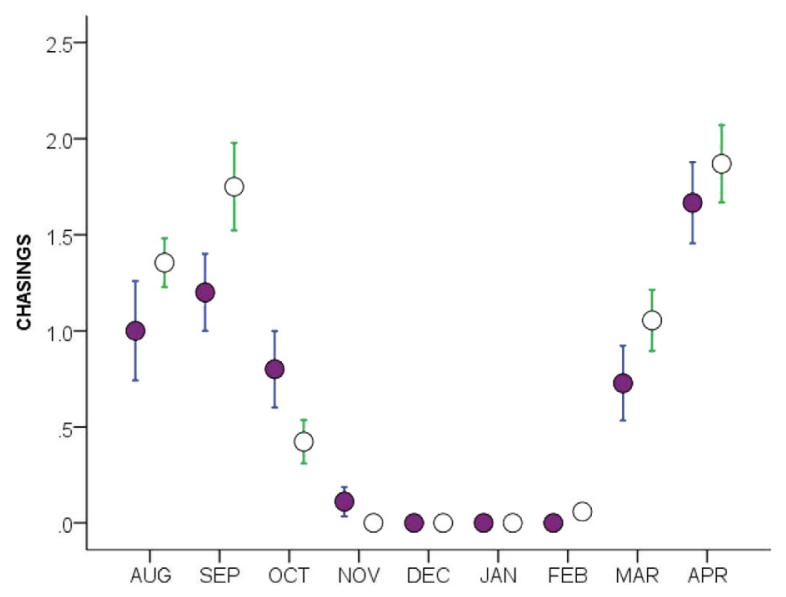

Figure 1. Mean monthly number of aggressive chasings per trip (mean \pm 1 S.E.) of Great Tits (filled dots) and Willow Tits (open dots) observed during the non-breeding seasons of 2004-2014 in the study area in Budal. For sample sizes see Table 1. 
for the Great Tits (Mann-Whitney U-test: $\mathrm{n}_{1}=16, \mathrm{n}_{2}=$ $27, \mathrm{z}=-0.29, \mathrm{p}=0.77)$ or for Willow Tits $\left(\mathrm{n}_{1}=77, \mathrm{n}_{2}=\right.$ $60, \mathrm{z}=-1.25, \mathrm{p}=0.21)$.

The number of chasings was positively correlated with ambient temperature in January-February for both species (Great Tit: Spearman rank-correlation $r_{s}=0.68$, $\mathrm{p}=0.003, \mathrm{n}=17$; Willow Tit: $\mathrm{r}_{\mathrm{s}}=0.73, \mathrm{p}<0.001, \mathrm{n}$ $=60)$.

Route to territorial ownership

The encounters among Great Tits recorded in AugustSeptember were most frequently recorded near feeders and were apparently, as previously suggested, to a large degree caused by competition for food. In MarchApril, however, most of the encounters were observed near nest-boxes and obviously reflected competition for territorial space. This assumption was strengthened by the different reactions of juvenile Great Tits to playbacks of song in the two periods. Playbacks of Great Tit song in August-September gave no response among juveniles, whereas playbacks in March-April gave response from two or more juveniles on seven out of eight occasions. Juvenile Willow Tits, on the other hand, reacted to playback of songs by a conspecific in both periods: six out of six occasions in AugustSeptember and eight out of eight occasions in March -April. The different reaction pattern between juvenile Great and Willow Tits differed significantly $\left(\chi^{2}=7.0\right.$, $\mathrm{df}=1, \mathrm{p}=0.008)$, and supports the prediction (2) that only the aggressive behaviour of Great Tits recorded in March-April is a result of territorial contests, whereas the aggressive behaviour of juvenile Willow Tits is linked to ownership of a prospective territory both in autumn and winter. If so, the route to territorial ownership differs between the two species.

Alpha pairs - intra-pair behaviour

Pair-bonds

Five of six alpha pairs of Great Tit (GT1-GT6) were followed successfully from November through February (Table 2). One of the pairs (GT1 in territory 1, 2011-12) kept together during the whole winter, but disappeared in April or May when an unknown adult Great Tit male (GT2) took over the nest box (territory 1) after intense fighting. The GT2-male mated in May with a young female from one of the winter flocks in

Table 2. Median distances $(\mathrm{m})$ between mates for five pairs of adult Great Tit territory holders (GT1-GT6) and for three pairs of adult Willow Tit territory holders (WT1-WT3) during November - December and during January - February in 2011-2014. Sample sizes in parentheses.

\begin{tabular}{|c|c|c|c|c|}
\hline & \multirow[t]{2}{*}{ Year } & \multirow[t]{2}{*}{ Pair } & \multicolumn{2}{|c|}{ Median distance (m) } \\
\hline & & & Nov-Dec (n) & Jan-Feb (n) \\
\hline \multirow[t]{9}{*}{ Great Tit } & 2011-12 & GT1 & $1.0(5)$ & $9.0(6)$ \\
\hline & $2012-13$ & GT2 & $3.0(2)$ & $3.5(2)$ \\
\hline & $2012-13$ & GT3 & $1.0(1)$ & $4.0(2)$ \\
\hline & $2013-14$ & GT2 & $5.0(4)$ & $8.0(3)$ \\
\hline & 2013-14 & GT3 & $6.0(1)$ & $7.5(4)$ \\
\hline & $2013-14$ & GT5 & $4.0(3)$ & $10.5(2)$ \\
\hline & $2013-14$ & GT6 & $8.0(3)$ & $15.0(1)$ \\
\hline & : 2011-2014 & GT1-6 & $4.0(19)$ & $8.0(20)$ \\
\hline & & & $\mathrm{Q}_{1}=1 ; \mathrm{Q}_{3}=8$ & $\mathrm{Q}_{1}=3.25 ; \mathrm{Q}_{3}=11.5$ \\
\hline \multirow[t]{11}{*}{ Willow Tit } & $2011-12$ & WT1 & $3.5(4)$ & $1.0(3)$ \\
\hline & $2011-12$ & WT2 & $2.0(4)$ & $1.0(3)$ \\
\hline & $2011-12$ & WT3 & $1.5(4)$ & $1.0(5)$ \\
\hline & $2012-13$ & WT1 & $1.0(7)$ & $1.0(4)$ \\
\hline & $2012-13$ & WT2 & $1.8(5)$ & $1.0(5)$ \\
\hline & $2012-13$ & WT3 & $1.5(2)$ & $1.0(6)$ \\
\hline & $2013-14$ & WT1 & $1.0(2)$ & $4.0(5)$ \\
\hline & 2013-14 & WT2 & $1.5(4)$ & $1.0(3)$ \\
\hline & $2013-14$ & WT3 & $1.0(3)$ & $1.5(2)$ \\
\hline & : 2011-2014 & WT1-3 & $1.0(35)$ & $1.0(36)$ \\
\hline & & & $\mathrm{Q}_{1}=1 ; \mathrm{Q}_{3}=3$ & $\mathrm{Q}_{1}=1 ; \mathrm{Q}_{3}=3$ \\
\hline
\end{tabular}


the area. This pair was observed together during the winters 2012-13 and 2013-14. Also the mates of pair GT3 (in territory 2) were observed together during the winters 2012-13 and 2013-14. The mates of pair GT5 (in territory 3) were observed together in 2013-14 until March when the female left her mate and was later seen together with another adult male about $500 \mathrm{~m}$ away. An adult pair (GT6 in territory 4) kept together until March when the female disappeared. An adult pair (GT4 in territory 5) disappeared in December without being replaced (data from these birds are omitted from the analyses). The cause of the disappearances of the GT4pair and the GT6-female is unknown.

Three alpha pairs of Willow Tits (WT1-WT3) were observed from November through February during the winters 2011-12, 2012-13 and 2013-14 (Table 2). One of the pairs (WT1) had defended their territory since 2010 and thus had kept together for at least four years. Both the pairs WT2 and WT3 were young birds that established their territories in 2011.

\section{Intra-pair distance}

Great Tit mates were observed closer together in early winter (November-December) than later (JanuaryFebruary; Table 2). The median distance between the mates during November-December was $4.0\left(\mathrm{Q}_{1}=1\right.$; $\mathrm{Q}_{3}=8$ ) metres and differed significantly from that of January-February, $8.0\left(\mathrm{Q}_{1}=3.25 ; \mathrm{Q}_{3}=11.5\right)$ metres (Mann-Whitney $\mathrm{U}: \mathrm{n}_{1}=19, \mathrm{n}_{2}=20, \mathrm{z}=-2.09, \mathrm{p}=$ 0.037).

The Willow Tit mates did not differ in their distances between early and late winters (Table 2). The median distance between the mates during NovemberDecember was $1.0\left(\mathrm{Q}_{1}=1 ; \mathrm{Q}_{3}=3\right)$ metres and did not differ from that of January - February, $1.0\left(\mathrm{Q}_{1}=1 ; \mathrm{Q}_{3}\right.$ =3) metres (Mann-Whitney $\mathrm{U}: \mathrm{n}_{1}=35, \mathrm{n}_{2}=36, \mathrm{z}=$ $-0.14, \mathrm{~ns})$.

Thus, as predicted (2), the Willow Tit mates kept closer together during the whole winter than did the Great Tit mates. Moreover, although the Great Tit mates often were observed together, the distance between the

Table 3. The number of interactions by alpha males when entering a feeder where their mate was staying. The male could attack his mate or he could wait to enter the feeder until his mate has left.

\begin{tabular}{lcc}
\hline Species & $\begin{array}{c}\text { Male attacks } \\
\text { female }\end{array}$ & $\begin{array}{c}\text { Male waits } \\
\text { for mate }\end{array}$ \\
\hline Great Tit & 22 & 3 \\
Willow Tit & 2 & 14 \\
\hline
\end{tabular}

mates increased later in the winter, whereas this was not the case in Willow Tits. The average distance between Willow Tit mates was shorter than that of Great Tits both in early (Mann-Whitney $\mathrm{U}: \mathrm{n}_{1}=19, \mathrm{n}_{2}=35, \mathrm{z}=$ $-3.1, \mathrm{p}=0.002)$ and late winter $\left(\mathrm{n}_{1}=20, \mathrm{n}_{2}=36, \mathrm{z}=\right.$ $-4.9, \mathrm{p}<0.001)$. Willow Tits were also observed more often in the same tree $(n=43)$ than were Great Tits $(n$ $=8$ ).

The distances between the mates were positively correlated with ambient temperature in JanuaryFebruary for both species (Great Tit: Spearman rankcorrelation $r_{s}=0.58, p=0.007, n=20$; Willow Tit: $r_{s}$ $=0.37, \mathrm{p}=0.027, \mathrm{n}=36$ ). In November-December, however, the distance between the mates was negatively correlated for the Great Tit $\left(\mathrm{r}_{\mathrm{s}}=-0.65, \mathrm{p}=0.003, \mathrm{n}\right.$ $=19)$, but not so for the Willow Tit $\left(\mathrm{r}_{\mathrm{s}}=-0.05, \mathrm{p}=\right.$ $0.80, \mathrm{n}=35$ ). Thus, whereas the mates of both species kept closer together in cold weather than in mild during January-February, Great Tit mates were most distant in cold weather in November-December. No such relationship was found for Willow Tit mates.

\section{Intra-pair conflicts}

Alpha pairs of both species exhibited a relatively low frequency of intra-pair conflicts. However, although Great Tit pairs were sometimes found close together outside the breeding season, often in neighbouring trees, the males disclosed their dominance to females, and frequently supplanted their mates when they had found a food item. On several occasions, female Great Tits apparently tried to avoid confrontations with their mate by either withdrawing or by waiting to visit the feeder until he had left. Willow Tit mates, on the other hand, were often observed close together without conflicts. Thus, when visiting a feeder, Great Tit males generally attacked his mate if she was at the feeder, whereas Willow Tit males seldom did so (prediction 3; Table 3). The difference in this behavioural pattern between the species is highly significant $\left(\chi^{2}=20.99\right.$, df $=1, \mathrm{p}<0.001$ ).

\section{Foraging and vigilance pattern}

As predicted (4), the foraging and vigilance patterns of the alpha females of Great and Willow Tits, when staying at a feeder, differed when their mate or when a juvenile male was close (within $2 \mathrm{~m}$ from the feeder; Table 4). The percentage of time devoted to foraging by a solitary female Great Tit was higher compared to that when she was feeding with her mate close $\left(\chi^{2}=\right.$ $4.97, \mathrm{df}=1, \mathrm{p}=0.026)$ or when a conspecific juvenile male was close $\left(\chi^{2}=6.39, \mathrm{df}=1, \mathrm{p}=0.001\right)$. Although insignificantly so, an alpha female Willow Tit devoted more time to foraging when her mate was close than 
Table 4. Mean percentage of observations of foraging (for) and vigilance (vig) at feeders by adult females in Great Tits and Willow Tits when being 1) solitary, 2) when their mates were close $(<2 \mathrm{~m})$, or 3$)$ when a conspecific juvenile male was close $(<2 \mathrm{~m})$. Figures in parentheses denote sample sizes.

\begin{tabular}{|c|c|c|c|}
\hline Species & $\begin{array}{c}\text { Solitary } \\
\text { for-vig (n) }\end{array}$ & $\begin{array}{l}\text { Mate close } \\
\text { for-vig (n) }\end{array}$ & $\begin{array}{l}\text { Juv male close } \\
\text { for-vig (n) }\end{array}$ \\
\hline Great Tit & $64-36$ & $13-87$ & $10-90 \quad(10)$ \\
\hline Willow Tit & $62-38 \quad$ (13) & $76-24 \quad$ (17) & $44-56 \quad(9)$ \\
\hline
\end{tabular}

when she was solitary on the feeder $\left(\chi^{2}=0.78, \mathrm{df}=1\right.$, $\mathrm{p}=0.38)$, but less time to foraging when a dominant juvenile male was close $\left(\chi^{2}=0.627, \mathrm{df}=1, \mathrm{p}=0.43\right)$. Whereas the mean foraging rate of the adult Great Tit females appeared to decrease by about $50 \%$ compared to the rate recorded when foraging without their mates or a juvenile male, the mean foraging rate of the adult Willow Tit females increased by $14 \%$ when their mates were close, but decreased by $18 \%$ when a juvenile male was close. The alpha male also often chased a juvenile male flock member that supplanted the alpha female. The alpha Willow Tit male apparently protected his mate from attacks by juvenile male flock members. Thus, in contrast to Great Tit females, the Willow Tit alpha female could reduce vigilance time used for scanning for higher ranked flock members or predators by staying close to her mate.

\section{DISCUSSION}

\section{Juvenile birds}

Avian winter flocks are generally assumed to form because each member avoids predation more effectively and may devote more time to foraging. The flock size of Great Tits can therefore be viewed as a compromise between advantages of living in groups and the costs of resource depletion by conspecifics. As more individuals are added to the groups, the individuals must expand their range to compensate for resource depletion. The loose organization of the winter flocks of Great Tits makes it possible for other conspecifics to enter the same area to seek for food and thus influence the access to food and flocking benefits of the local birds. In this respect Great Tits differ from most other tit species (Matthysen 1990). The visitors are frequently attacked by members of the local flocks. The aggressive behaviour of Great Tits recorded in August - September may therefore primarily serve the purpose of securing priority to food resources rather than excluding intruders. The lack of reaction of the juveniles to the play backs of song may strengthen this assumption.
This assumption is in accordance with earlier findings of aggressive behaviour within Great Tit winter flocks: two peaks, one in first half of December, assumed to be related to food and density-dependence, and the other in February, assumed to be related to establishment of breeding territories (e.g. DeLaet 1984).

The number of chasings in March-April was positively correlated with temperature for both species, strongly indicating that the birds were more aggressive on days with relatively high temperatures because aggression is suppressed on cold days due to increased costs of energetic stress (cf. Hogstad 1988).

Because favourable habitats are largely saturated with dominant Willow Tit territory owners, there is a limit to the number of winter flocks an area can accommodate. As also the flock size apparently is limited, and flock membership in general is the only possible way to territory ownership (e.g. Hogstad 1999), the aggressive behaviour recorded among juvenile Willow Tits in autumn is most likely linked to territorial behaviour. Thus, flock-living in juvenile Willow Tits may be described as a conditional strategy, dependent on availability of vacancies for juvenile territoriality.

Although Great and Willow Tits may have a similar actual flock size, the flock structure is different. Most Great Tit flocks consist of an adult pair and varying number of unpaired juveniles, whereas the common Willow Tit flock consists of an adult pair and two juvenile paired birds that share a fixed dominance position within the flock. Great Tit juveniles therefor have the possibility to insert themselves in a high-rank position immediately by paring with a widowed bird. Juvenile Willow Tits, on the other hand, are paired and seem to be locked into their rank by their pair bond and seldom divorce to form a pair with another bird in the same flock. Instead they usually replace widowed birds as a pair (Hogstad 1999).

Due to a relatively high overwinter survival of adult and first-year birds in the area, and new territories seldom are established during spring, the local breeding population is limited by the number of actual territories established the previous year. At the end of February or 
during March-April, the large winter flocks of Great Tits break up and adult pairs or adult males return to their territories, i.e. to their nest boxes occupied the previous year. This is the period when surviving juvenile males stay around retained boundaries of territorial adult males and frequently challenge territory owners. Also among juvenile Willow Tits, that regularly update their information about the dominance structure of adjacent winter flocks by visiting them in attempt to become dominant owners during winter (Hogstad 1999), there is a marked increase in aggressive behaviour towards adults as well as towards other juveniles during late winter.

\section{Alpha pairs}

The present study points out circumstances entailing benefits of the pair bond for Willow Tits that differ from that of Great Tit alpha pairs: the mate attentiveness was significantly higher in Willow Tits than between Great Tit pairs, the mates of Willow Tits kept closer together, generally without intra-pair conflicts, and the male apparently protected his mate from juvenile males that normally were dominant over the female. Alpha Willow Tit males have also been found to give alarm calling to warn his mate, even when exposing himself to a predator (Hogstad 1995). However, despite the Great Tit male's dominance behaviour towards his mate, as described in the present study, males obviously may show mate protection. Krams et al. (2006) found that male Great Tits gave alarm calls when observing a predator when accompanied by their mate, but less frequently when foraging alone, or when in the company of unfamiliar Great Tits outside their usual home-range.

The increased distance between the mates of Great Tits in late autumn versus early winter may be a result of food depletion in the course of the winter. However, the reduced distances between the alpha mates of both species in cold weather compared to that observed in mild weather, are probably a result of the "many eyes-effect" towards predators. Since energy demands increase with low temperature and the advantages of flocking increase with food demand, the presence of many eyes improves the efficiency of predation detection by flocks and increases the time for foraging (e.g. Hogstad 1988).

By foraging close to his mate, Willow Tit females may reduce their vigilance for potential aggressors and thereby increase the time available for foraging. It has earlier been demonstrated that mate protection is responsible for an enhanced nutritional condition of females paired to alphas (Hogstad 1992). Since winter survival in parids can be related to food availability and its effect on exposure to predators (e.g. Jansson et al. 1981, Hogstad 1992), there is a strong link between mate protection and the survival of paired females.
It may therefore be suggested that mate protection in Willow Tits may be an important factor in explaining the similar winter survival rates between the sexes of adults (e.g. Orell et al. 1994, Hogstad unpublished data). As Willow Tits commonly pair for life (Hogstad, unpublished data), it seems likely that mate protection strengthens long-term bonding and confers considerable reproductive advantages as found in many species (e.g. McGraw \& Hill 2004).

Correspondingly, the reduced foraging rate of female alpha Great Tits when in company with her mate or a socially dominant juvenile male, may be one of the factors responsible for the lower winter survival of adult females than that of males (Gosler 1993, Koivula et al. 1996, Hogstad unpublished data).

The mates of the Willow Tit alpha pairs were in general seen together within their territories during the winter months (e.g. Hogstad 1999). The three adult pairs of Willow Tits that were observed during the winters 2011-2014, and the pair that had defended their territory for at least four years, demonstrate longterm mate and site fidelity. In contrast to the Willow Tits, where I have not observed divorce among adults during my 35 years study in the Budal area, Great Tits apparently may divorce. The female of one pair (GT6) that disappeared in March, and especially the female of pair (GT5) that left her mate and was later observed together with another adult male, strongly suggests divorce. The divorce rate of Great Tits in Finland has been estimated to 12\% (Orell et al. 1994), in Germany 24\% (Pampus et al. 2005), and in Japan $18 \%$ over 10 years (Saitou 2002, Saitou \& Asakawa 2009). In a homogeneous habitat in eastern Spain, 33\% of the breeding pairs of adult Great Tits changed their territory between seasons, and only about two thirds of the birds kept the same mate in consecutive years (Andreu \& Barba 2006).

Differences in divorce rate between Willow and Great Tits may partly be a result of differences in the cost of finding a new partner. Such costs may be influenced by the social organization during the non-breeding season. If pairs remain on the territory, as do Willow Tits, the search costs may be higher and divorce rates lower compared to Great Tit pairs that move around irrespective of territorial ranges. However, although the extent of extra-pair young in the Willow Tit is amongst the lowest recorded in non-passerines and passerines (e.g. Birkhead \& Møller 1992), 1\%-11\% of sampled nestlings were classified as extra-pair young in Finnish populations (Koivula et al. 1991, Rytkönen et al. 2007, Lampila et al. 2011).

The duration of the pair bond is regarded as important determinant of breeding onset, and birds remaining paired together across seasons have been found to initiate breeding earlier than newly formed pairs (see Fowler 1995). Long-term pair-bonded males and females might therefore be expected to show mutual 
interest in defending their mate. Furthermore, because Willow Tits store food within their territory, there is an extra benefit in having a close social bond in order to defend their caches. The influence of social dominance by male Great Tits on winter survival of females (e.g. Gosler 1993), however, may also influence the pair bond stability of the species. Because females are less likely to survive during the winter, it may be expected that some males are unable to find a mate in the spring. If so, this may explain the relatively greater variation in the breeding population density of Great Tits compared with that of the Willow Tits in northern Finland (Orell 1983) and in the subalpine forest in my Budalen study area (Hogstad unpublished data).

\section{REFERENCES}

Andreu, J. \& Barba, E. 2006. Breeding dispersal of Great Tits Parus major in a homogeneous habitat: effects of sex, age, and mating status. Ardea 94: 45-58.

Birkhead, T.R. \& Møller, A.P. 1992. Sperm competition in birds. Evolutionary causes and consequences. Academic Press, London.

DeLaet, J. 1984. Site-related dominance in the Great Tit Parus major. Ornis Scandinavica 15: 73-78.

Ekman, J. 1979. Coherence, composition and territories of winter social groups of Willow Tit Parus montanus and the Crested Tit P. cristatus. Ornis Scandinavica 10: 56-68.

Fowler, G.S. 1995. Stages of age-related reproductive success in birds: simultaneous effects of age, pair-bond duration and reproductive experience. American Zoologist 35: 318-328.

Gosler, A. 1993. The Great Tit. Hamlyn, London.

Hogstad, O. 1987. Social rank in winter flocks of Willow Tits Parus montanus. Ibis 129: 1-9.

Hogstad, O. 1988. Advantages of social foraging of Willow Tits Parus montanus. Ibis 130: 275-283.

Hogstad, O. 1992. Mate protection in alpha pairs of wintering Willow Tits, Parus montanus. Animal Behaviour 43: 323-328.

Hogstad, O. 1995. Alarm calling by Willow Tits, Parus montanus, as mate investment. Animal Behaviour 49: 221-225.

Hogstad, O. 1999. Territory acquisition during winter by juvenile Willow Tits Parus montanus. Ibis 141: 615-620.

Hogstad, O. 2003. Strained energy budget of floaters in the Willow Tit as indicated by ptilochronology. Ibis 145 online: $1-5$.

Hogstad, O. 2014. Pair-bond formation and mate fidelity among juvenile Willow Tits. Ornis Norvegica 37: 7-10.

Jansson, C.J., Ekman, J. \& von Brömssen, A. 1981. Winter mortality and food supply in tits Parus spp. Oikos 37: 313-322.
Koivula, K., Orell, M. \& Rytkönen, S. 1991. Mate guarding in forest-living, territorial Willow Tits. Ornis Fennica 68: 105-113.

Koivula, K., Orell, M. \& Rytkönen, S. 1996. Winter survival and breeding success of dominant and subordinate Willow Tits Parus montanus. Ibis 138: 624-629.

Krams, I., Krama, T. \& Igaune, K. 2006. Alarm calls of wintering Great Tits Parus major: warning of mate, reciprocal altruism or a message to the predator? Journal of Avian Biology 37: 132-136.

Laaksonen, M. \& Lehikoinen, E. 1976. Age determinations of Willow and Crested Tit Parus montanus and P. cristatus. Ornis Fennica 53: 9-14.

Lampila, S., Orell, M. \& Kvist, L. 2011. Willow Tit Parus montanus extrapair offspring are more heterozygous than their maternal half-siblings. Journal of Avian Biology 42: 355-362.

Lendrem, D.W. 1983. Predation risk and vigilance in the Blue Tit (Parus caeruleus). Behavioral Ecology and Sociobiology 14: 9-13.

Matthysen, E. 1990. Nonbreeding social organization in Parus. Current Ornithology 7: 209-249.

McGraw, K.J. \& Hill, G.E. 2004. Mate attentiveness, seasonal timing of breeding and long-term pair bonding in the House Finch (Carpodacus mexicanus). Behaviour 141: 1-13.

Orell, M. 1983. Breeding and mortality in the Great Tit Parus major and the Willow Tit P. montanus. Ph.D.thesis, University of Oulu, Finland.

Orell, M., Rytkönen, S. \& Koivula, K. 1994. Causes of divorce in the monogamous Willow Tit Parus montanus and consequences for reproductive success. Animal Behaviour 48: 1143-1154.

Pampus, M., Schmidt, K.H. \& Wiltschko, W. 2005. Pair bond and breeding success in Blue Tits Parus caeruleus and Great Tits Parus major. Ibis 147: 92-108.

Rytkönen, S., Kvist, L., Mikkonen, R. \& Orell, M. 2007. Intensity of nest defence is not related to degree of paternity in the Willow Tit Parus montanus. Journal of Avian Biology 38: 273-277.

Saitou, T. 1978. Ecological study of social organization in the Great Tit, Parus major L. I. Basic structure of the winter flocks. Japanese Journal of Ecology 28: 199-214.

Saitou, T. 2002. Factors affecting divorce in the Great Tit Parus major. Ibis 144: 311-316.

Saitou, T. \& Asakawa, M. 2009. Breeding population of the Great Tit Parus major. Journal of the Yamashina Institute of Ornithology 40: 104-116.

Svensson, L. 1992. Identification guide to European Passerines. 4th edn. Fingraf, Södertälje.

Received 23 February 2015. Accepted 20 April 2015 